\title{
READING ARENDT TO RETHINK TRUTH, SCIENCE, AND POLITICS IN THE ERA OF FAKE NEWS
}

\author{
Federica Merenda
}

\section{Introduction}

"No one has ever doubted that truth and politics are on rather bad terms with each other, and no one, as far as I know, has ever counted truthfulness among the political virtues" (Arendt 1967: 295).

In spite of the success of such "commonplace" mentioned by Hannah Arendt at the very beginning of her reflections on Truth and Politics, in 21st century contemporary democracies truth, lies, and political opinions are very intertwined concepts. Expressions like "post-truth politics" and "fake news" by now entered the vocabulary of politics, and they are employed more and more to describe relevant dynamics of the contemporary political discourse.

We live in times when it is not easy at all to distinguish between facts, mystification of facts - which contain some truths well-mingled with a high dose of distorted information - blatant lies, and political opinions. While reading the newspaper or scrolling through the social media newsfeeds of politicians directly speaking to "the people" through Facebook live videos - a habit which became particularly massive during the recent outbreak of Covid-19, when Facebook live-streaming in some countries replaced the usual institutional broadcasting on national television - we sometimes feel outraged as we spot blatant lies or traces of wisely hidden truths in political speeches (or tweets), or when we witness political leaders endorse information soon after unveiled as fake news.

Sharing Arendt's view that philosophy can help us to understand reality and to reconcile ourselves with the world we live in (Arendt 1994: 308), this chapter will consider relevant concepts and paradigms elaborated in Arendt's works, which have been at the centre of modern and contemporary Western political thought even beyond Arendt. This conceptual toolbox purposely would help to clarify the 
relation between (the different kinds of) truth, (the different kinds of) lying, and politics in contemporary democracies.

\section{Contextualising Arendt: On truth and politics in Western philosophy}

In order to examine the relationship between truth and politics, we move from Arendt's distinction between different kinds of truth and even different degrees of lying. Identifying which truths possess a political value of some sort presupposes pondering even more basic questions that philosophers well before Arendt have tried to respond to: does truth exist as such? In case it exists, is it intelligible? And when it is not, is it dispensable? Can we talk about any knowledge at all beyond objective truths? Which kinds of truths are at odds with democracy and which are necessary for its wellbeing?

The many different answers to these questions gave rise to different approaches to science, philosophy, and political theory. The discussions concerning whether truth can be deemed to exist as such and whether, in that case, it would be accessible to human knowledge are indeed deeply intertwined with the epistemological question of whether natural or philosophical truths could - and/or should constitute the ultimate object of philosophical or scientific research and of the appropriateness of such pursuit as the qualifying characteristic of science.

While pre-Socratic philosophers looked for the ultimate principle of natural reality, thereafter, spanning from the Cave in Plato's myth to Schopenhauer's Veil of Maya (Schopenhauer 1995) and through Kant's Critiques, the idea that objective truth and the representation of reality by human beings, as a subjective perception or interpretation, may be two different things deeply affected the evolution of philosophical thought, and that of political theory. ${ }^{1}$

In the 18th century, Immanuel Kant shifted the focus of philosophical research from objective truth, as the study of an outer object, to the subject of knowledge and thus to human rationality, morality, and judgment (Kant 2007a; 2007b; 2012), to explore the way in which we, as human beings, perceive ourselves and the outer world. This brief premise shows the relevance of the subject we are treating in all the philosophical production; a philosophical production that our examination has not the ambition to analyse thoroughly but that constitutes the humus in which Arendt's reflections on truth and politics - and contemporary further explorations could emerge.

In order to contextualise Arendt's definition of truth and truths and their relationship with democratic politics, we adopt the distinction drawn by Antonella Besussi $(2013 ; 2015)$ in her work devoted to the concept of truth in contemporary political philosophy. Besussi usefully distinguishes between those political theories suggesting a banalisation of the relationship between truth and politics and those tending towards a dramatisation: it is in this second group that we find Arendt.

The perspective of those allegedly banalising such relation is quite clear-cut in its premises: according to these thinkers, there is no objective truth at all to be found 
out beyond our subjective interpretations. To bring this belief to its extreme would mean to say that there is no such thing as objective facts: subjective interpretations of reality are all we have. We can ponder whether it is convenient or not to attribute to our subjective interpretations of the world the characteristics of truth, that is to present them as undisputable. As an objective truth does not exist, to attribute the quality of truth to our subjective interpretations of the world will thus be a decision that we will take considering what truth does rather than what it is, ${ }^{2}$ in a consequentialist perspective.

On the other hand, political theorists who dramatise the relationship between truth and politics are not expressly excluding the possibility that an objective truth does exist. Facts do exist. What they point out is rather that, for different reasons, there is an incompatibility between truth and politics, supporting the idea that truth has no place in the political democratic realm, at least in ordinary circumstances. Such dramatisation, in Besussi's taxonomy, assumed two different forms. The former is that of a "realistic conception of truth". ${ }^{3}$ In this view, truth does not concern politics in as far as the objective of democratic politics is not to ascertain which human representation of reality does correspond to truth.

More specifically, politics should deliberate which principles a specific society gives priority to in a specific moment of its history, among those embodied in the programmes and policies proposed by the different competing political parties. These philosophers accept that individuals and groups can believe in comprehensive paradigms that give rise to the principles they support within the democratic competition, but once such principles enter the realm of democratic politics they become just alternative policies competing for consensus. As Norberto Bobbio would say, the discourse over the foundations of such principles is left outside the political arena which is just concerned about their possibility to be agreed on (Bobbio 1997).

Quite differently, Hannah Arendt endorses, similarly to John Rawls, a "valuebased conception of truth" by refusing to recognise truth as an absolute standard in the public sphere, from an anti-authoritarian stance. In Rawls' Political Liberalism (Rawls 2005), the principles of justice of a well-ordered society are proposed not because they are the true right principles per se, but because they are the ones that supposedly would be agreed on by individuals finding themselves in an ideal original position. The overlapping consensus is their source of legitimacy, and thus they are political principles, not moral ones. The function used by Rawls to identify them is political consensus, not truth, even if the first is conceived in an abstract way by means of a mental experiment. To accept truth within the wellordered society would make the overlapping consensus impossible, as truth accepts no compromise.

Such incompatibility between truth and democratic compromise is strongly perceived by Arendt as well: this is the element that will bring her in going deep in elaborating the taxonomy of truth, truths, and lying which we think does constitute a particularly useful conceptual tool for contemporary reflections. We will examine Arendt's conceptualisation thoroughly in our next section, mainly referring to her 
works on Truth and Politics (Arendt 1967) and Lying in Politics (Arendt 1969) but having in mind her much wider philosophical production.

\section{Factual truths, philosophical truths, and lying in politics: Arendt's perspective}

In her reflection on Truth and Politics, Arendt (1967) distinguishes between factual truths (facts, events) and rational truths (e.g. mathematical, scientific and philosophical truths) to specify the different relations they have with the political debate in a plural society and to investigate the consequences of their negation or mystification.

In Arendt's definition, factual truths are just factual statements which describe facts and events: with reasonable approximation - an approximation justified by common sense, a crucial concept in Arendt's discourse (Arendt 1982) - to say "It rains", when it is actually raining, is a factual truth. Rational truths (a category which also includes philosophical and religious truths) are instead expressed in the form of statements like "two plus two is four" or "God exists".

What they both have in common is that they imply an element of coercion:

Statements such as 'The three angles of a triangle are equal to two angles of a square,' 'The earth moves around the sun,' 'It is better to suffer wrong than to do wrong', 'In August 1914 Germany invaded Belgium' are very different in the way they are arrived at, but, once perceived as true and pronounced to be so, they have in common that they are beyond agreement, dispute, opinion, or consent

(Arendt 1982: 302).

In Arendt's view, any truth is coercive because it is beyond agreement, dispute, opinion, or consent, which are precisely those elements that, as we found in Rawls, make the democratic politics of the overlapping consensus possible. In this being undisputable and non-negotiable, truth is intrinsically anti-democratic. Yet, the distinction between factual truths and rational ones is crucial.

Factual truths, while being at odds with the political debate, are necessary for the exercise of democratic power in a plural society. Also, this is the category which acquires critical relevance today with reference to the problem of fake news: it is factual truths that fake news denies On the contrary, according to Arendt, rational truths are both generally at odds with the political debate and also at odds with the exercise of democratic power in a plural society: as truth is not democratic, it does not allow for the plurality of opinions which is the essential nourishment of democracy.

The content of rational truths can be admitted to the public sphere of democratic politics only in the form of a mere opinion among other opinions, which does not carry with its coercive value of truthfulness, and as long as it accepts to give up such claim for truthfulness. For instance, a political party can inform 
its action to religious values but it cannot do so by presenting its policies as the only true actions to take. Such religious values can enter the political arena just as opinions.

On the other hand, factual truths, while being at odds with the political debate in their being uncontroversial, are not only totally compatible with democratic politics but even necessary for it. While this can appear contradictory, it works if we accept that facts belong to another dimension, which is placed underneath that of politics itself. "Facts and events [. . .] constitute the very texture of the political realm" (ibid.: 297), they are the ground political opinions can be built upon. If we do not agree on the facts at hand, we cannot appropriately start any discussion about how to deal with them, exchanging our opinions on the issue.

While science and philosophy are the dimension of rational truths, politics is thus the realm of opinions, which is grounded on an underlying layer of factual truths. This ground is solid as long as it is not put into question, as long as its validity is not doubted. When facts are not universally recognised and their truthfulness is put into question, when the question "Is it really true that it's raining?" is asked, deliberate lying can make its appearance in the public discourse and the ground which the political discourse is built upon, "the ground on which we stand and the sky that stretches above us" (ibid.: 313) starts shaking.

\section{Fake news: Mingling lies, facts, and opinions}

While we find Arendt's definitions very useful, it is crucial to note that by driving distinctions between ordinary conditions and moments when "a community has embarked on organized lying on principle" (ibid.: 307) she was referring to totalitarianism. In that context, Arendt was able to identify more clear-cut dynamics and concepts than what are commonly at work today in post-truth democracies where populist forces are operating.

To distinguish between a healthy relation linking truth and politics and the perversion of such relation is more subtle if we want to apply Arendt's categories not in the most radical context of totalitarian states but in the slippery slope between a well-functioning democracy and populist regimes.

Still, rather than making our effort futile, such blurred conditions characterising the contemporary situation on the contrary make any attempt at a conceptual clarification even more necessary. In the public sphere of our contemporary liberal democracies, we can discuss, argue, and compare different opinions about how to deal with a particular fact or event, for instance climate change, only once we agree that climate change is a reality. Once we acknowledge that climate change is happening, each individual and each community involved can do their part to deal with the consequences of such an alarming fact. Experts can help to clarify the facts, identify the causes of the phenomenon, and the practices that are worsening it.

Politicians can then propose different alternatives on how to face climate change in practice, with each alternative endowing competing values, rights, interests, and 
priorities. There are many possible alternatives to reach the same goal: for instance, according to their priorities and political values, to fight climate change politicians can propose policies on measures that do not disproportionally affect the most vulnerable countries and individuals, or alternative ones that give priority to protecting the interests of the private sector.

Journalists can provide the general public with accurate information both about climate change itself and about the policies currently under consideration by the different political parties and leaders. However, if some authoritative figure, let's say the President of the United States, denies climate change as a fact by releasing declarations like "I don't believe it" and "The concept of global warning was created by and for the Chinese in order to make US manufacturing non-competitive" (Cheung 2020), at least part of the public debate is diverted from the confrontation between the different political options at disposal to fight climate change to a debate on whether climate change is actually happening or whether it is just a total mischief, an exaggeration, a plan of the Chinese government to disrupt the US as an economic power, a lie construed by those enterprises which have invested in green energy, and so on.

This is a clear example of a negation of a fact: in this case, President Trump firstly put climate change into question and then created an alternative version of reality, a plain lie, that once pronounced by such an authoritative source entered in competition with the factual truth of climate change. Though the contemporary political regime in place in the US is not a totalitarian one, having the President releasing such declaration is still worrying for democracy. Unfortunately, we are witnessing similar dynamics in these very days with regards to Covid-19, not only in the US, but also in other Western democracies (Soubhik et al. 2020).

To reflect upon these contemporary cases, an operative way to think about truth which could be particularly useful, and that we find very much in line with Arendt's conceptual toolkit that we have hereby adopted, has been elaborated by Franca D'Agostini in her work Introduction to Truth (D'Agostini 2011). Here, she invites the reader to consider truth not as a substantial content per se (which would make it correspond to a specific truth) but as a conceptual function, a quality that statements may or may not have or acquire. In mathematical language, we would thus represent truth not as a variable $x$ but as a function $f(x)$ - as a question, rather than as an answer. By applying this definition, we can thus generally state that to think about truth means to think about whether the question "Is it true or not?" can be applied to our perceptions, representations, interpretations of reality.

Once we ask such question, irrespective of the answer we get, truth has entered the dimension of our discourse. When, on the contrary, we implicitly assume a statement as uncontroversial, we are considering it a fact, by excluding the possible debate on its truthfulness or falsity from our concern and thus leaving it in the background of our discourse, not applying the function. As an example, we can take the Preamble of the American Declaration of Independence. By writing "we hold these truths to be self-evident", ${ }^{4}$ Thomas Jefferson and his peers made 
the political-philosophical principles included in the Declaration, among which the principle that "all men are created equal", uncontroversial; they transformed them into facts. The question "is it true that all men are equal?" is pre-emptively displaced because such principle is placed in the sphere of facts, which is beyond arguments. Facts are assumed as truths without the question on their truthfulness even being asked, because to ask that question would mean to doubt them.

The question of the relation between truth and politics can thus be translated into the appropriateness of asking this question about statements expressed in the public sphere: is it appropriate to apply truthfulness as a standard in politics, to ask whether what a politician says is true or not? Whether the political solutions suggested are the true answer to political problems? Or should we just focus on whether we would wish those policies to be adopted in view of their consequences? Do facts have a place in politics? And what is the role of other subjects participating in the public debate, spanning from the common citizen to journalists, public figures or intellectuals?

When there are politicians denying facts, truth makes its appearance within the political realm, where it does not belong. When political figures and those exercising public powers lie about factual truths, they bring facts from the background of the political sphere to the political arena itself, that as we said is the realm of opinions. In these cases, truth as a function is applied to facts which, as such, should be considered instead uncontroversial and accepted as they are.

As the truthfulness of such facts is doubted or negated, they are brought by their detractors to the political arena, where they are attacked by fake news through the means employed in the competition between different opinions: in order to be chosen among competing ones, they are asked to be convincing.

But truth is seldom convincing in its being accidental. Factual truths are not opinions resulting from accurate reasoning or reflections with a teleological scope. Therefore, facts cannot be exhaustively explained or thoroughly understood. In this sense they are accidental. They can only be witnessed and believed. It is thus more a question of faith, or at least trust, in the source of information than a matter of epistemic resources of the recipients of the information themselves. As Arendt warns us, lies are usually much easier to believe than factual truths and thus they can be far more persuasive:

Since the liar is free to fashion his 'facts' to fit the profit and pleasure, or even the mere expectations, of his audience, the chances are that he will be more persuasive than the truth-teller. Indeed, he will usually have plausibility on his side; his exposition will sound more logical, as it were, since the element of unexpectedness - one of the outstanding characteristics of all events - has mercifully disappeared

(Arendt 1967: 307).

The more and more scientists, intellectuals, and scholars are called upon in the public debate to present hard data, "neutral" information that the audience can 
cling on to in such uncertain times when factual truths are blatantly negated by populist leaders and intellectually dishonest politicians. Experts' action is crucial. In ordinary circumstances, stating facts is not to be considered a political action as acknowledging something that already exists does not give origins to anything new, which is the characteristic of human action in Arendt's wording. Still, when a community has embarked upon

organized lying on principle, and not only with respect to particulars, can truthfulness as such, unsupported by the distorting forces of power and interest, become a political factor of the first order. Where everybody lies about everything of importance, the truth-teller, whether he knows it or not, has begun to act; he, too, has engaged himself in political business, for, in the unlikely event that he survives, he has made a start toward changing the world

(ibid.).

\section{The noblest contribution of intellectual labour: Conclusive remarks}

These reflections are deeply intertwined with Arendt's peculiar idea of politics, which is very close to the isonomia of the polis in Ancient Greece, as she points out in all her works and she particularly explores in The Human Condition (Arendt 1958). Such idea of democratic power is in a way the contrary to dominion and totalitarianism and is therefore a good antidote to totalitarian tendencies in weak democracies. ${ }^{5}$

According to Arendt, philosophers, scientists, politicians, and common citizens are part of the same community of human beings precisely in virtue of sharing the common ground of facts, the world of things that connects yet holds us apart. It is the plurality of the human condition itself to be embroidered within "the common world that unites and separates us" (Arendt 1958), the world of facts, events and accidents over and among which human action can be performed. The very existence of such a world makes us a plurality by connecting us through our sharing it. Still, such a world is common as long as we share a common sense that enables us to understand each other: the common sense that is necessary to name things and to discuss them, trusting the fact that when we say something the person we are talking to gets pretty much a similar idea of what we have in mind while saying the word. When lies are so widespread as to have become undistinguishable from facts, our common sense is lost.

The loss of common sense would be such a radical problem that among contemporary reflections on post-truth politics, there are some that consider it as just a symptom of a more fundamental problem:

More than cause of the state of crisis of contemporary liberal democracies, post-truth is the visible symptom of a deeper problem, which in 
philosophical terms could be rendered as hyper-individualism or radical subjectivism, which is perhaps best expressed using a word from ordinary language: solitude

(Alagna 2019).

When factual truth is put into question, denied and substituted by deliberate lies, we may start to have reasons to worry about the ability of democratic guarantees to prevent any political discourse paving the way for an exercise of power that reminds us more of political dominion than of democratic power.

More radically, when the practice of organised lying becomes systematic and we lose trust in political institutions and in each other as epistemic sources, we may worry that it is thus sociability and, as a result, politics itself that is endangered.

Arendt is quite optimistic about the fact that, as long as there are witnesses and truth-tellers, in the long run truth will outlive organised lying (Arendt 1967). Yet, nowadays, direct confrontations between 'experts' and lying politicians do not too often end with the first category winning the debate and this is not seemingly managing to disrupt lying on factual truths as a political strategy. When thinking about the contemporary fake-news politics scenario as this book is seeking to do, we need to take into account elements which are peculiar to current times, contextual elements which have an impact on the success of the strategies to rebuild a stability for the shaking ground we stand on. First of all, we could provocatively ask how relevant 'the long run' in which Arendt puts her confidence in is in such times of short-sighted political propaganda, which usually aims at winning one debate today with all the arms at its disposal without caring that much about lies being uncovered afterwards. If we go from election to election, we risk 'the long run' to never come.

Secondly, to have experts battling against politicians on social networks or onscreen television debates, extrapolated from their institutional environment, is tangibly bringing factual truth into the political dimension where it does not belong. When Arendt calls upon intellectuals, journalists, historians to be truthtellers, she does not suggest that they engage in direct competition against the lying politicians, nor that they replace them by calling experts to take political decisions instead of politicians. The risk of further mingling facts with politics is high. This neither helps the authoritativeness of science nor that of politics itself. Experts and politicians have very different roles and even when the former play a 'political' role through their stating of facts, they do not at all exhaust politics as such. On the contrary, experts' role should always be ancillary to that of politicians. For Arendt, stating factual truth is essential in helping us to understand what political actors should not do, rather than what they must (Sorrentino 2013: 90).

Once facts are to a certain extent shared - and we are aware, as Arendt herself surely was, that considering factual truths undisputable is simplistic, as there can be disagreements on facts even among 'experts' - it is up to those exercising the political powers to propose policies on how to tackle them by taking into account different concerns at the same time and prioritising over certain values, 
objectives, issues instead of others. The contribution that the 'science' of political philosophy can offer to politics is to provide citizens, other than politicians, with conceptual instruments aimed at achieving clarity in their discourse. This is what Weber calls the "ethical achievement" of science in politics at the end on his lecture on 'Science as vocation' (Weber 2004). Once facts are restated, the democratic debate among different political opinions can - and must, to have a functioning democracy - restart; the responsibility for this stands with politics, not with science. ${ }^{6}$

\section{Notes}

1 To contextualise Arendt's reflections, which will be examined in the second section of this chapter, see Sorrentino (2017).

2 In Besussi's recollection, such premise is shared and differently articulated by Richard Rorty, Hilary Putnam, Jürgen Habermas, Michel Foucault, Bernard Williams and Ronald Dworkin. See Besussi (2013:9-27).

3 According to Besussi (2013), such perspective is shared by Hans Kelsen, Max Weber and Leo Strauss.

4 Declaration of Independence: a transcription (1776) US National Archives, available at www. archives.gov/founding-docs/declaration-transcript (last consulted 1 April 2020).

5 See Cavarero (2019).

6 "The objective knowledge of science is not just true, it is useful too: it provides us with notions to orient ourselves in the world and it trains us at thinking, teaching us a logical and methodological accuracy that is valuable notwithstanding the action we intend to perform [...] Also, it defies factual beliefs which are not objective, it unveils value-judgements disguised as factual truths, it solves moral disagreements resulting from lying on facts or reasonings which are logically unsound [. . . This ability to achieve clarity through statements which are "true" is the meaning, the significance, the major and noblest contribution of intellectual labour. And that is so mainly as, by fostering a sense of responsibility, it positively influences the behaviour of political actors" (Ferrera 2013: 52).

\section{References}

Alagna, M. (2019) 'The ground trembling under our feet. Truth, politics and solitude', Soft Power 6(2): 111-29.

Arendt, H. (1958) The Human Condition, second edition, Chicago: University of Chicago Press.

Arendt, H. (1967/2005) 'Truth and politics', in J. Medina., D. Wood (eds), Truth: Engagements Across Philosophical Traditions, London - New York: Wiley-Blackwell.

Arendt, H. (1969) Lying in Politics. Reflections on the Pentagon Papers, New York: Harcourt Brace Jovanovich.

Arendt, H. (1982) Lectures on Kant's Political Philosophy, Brighton: Harvester.

Arendt, H. (1994) (or. ed. 1954) 'Understanding and politics', in: Ead., Essays on Understanding 1930-1954: Formation, Exile and Totalitarianism, New York: Schoken Books.

Besussi, A. (ed.) (2013) Verità e politica. Filosofie contemporanee, Roma: Carocci.

Besussi, A. (ed.) (2015) Filosofia, verità e politica. Questioni classiche, Roma: Carocci.

Bobbio, N. (1997) 'Sul fondamento dei diritti dell'uomo?', in: Id., L'età dei diritti, Torino: Einaudi.

Castelli, F. (2012) 'Le verità della Politica. Hannah Arendt sul rapporto tra Verità, Menzogna e Potere', in: A. Pimi (ed.), Verità del potere, potere della verità, Pisa: ETS. 
Cavarero, A. (2019) Democrazia sorgiva. Note sul pensiero politico di Hannah Arendt, Milano: Raffaello Cortina Editore.

Cheung, H. (2020) 'What does Trump actually believe on climate change?', BBC, 23 January 2020, www.bbc.com/news/world-us-canada-51213003 (last consulted 1 April 2020).

Cotroneo, G. (2012), 'L'avventura della menzogna politica', Filosofia Politica, XXVI(3): $463-70$.

D'Agostini, F. (2011) Intoduzione alla verità, Torino: Bollati Boringhieri.

D’Agostini, F., M. Ferrera (2019) La verità al potere. Sei divitti aletici, Torino: Einaudi.

Ferraris, M. (2017) Postverità e altri enigmi, Bologna: Il Mulino.

Ferrera, M. (2013) 'Max Weber: Verità e responsabilità. Il binomio virtuoso', in: A. Besussi (ed.), Verità e politica, Roma: Carocci, 48-65.

Kant, I. (2007a) (or. ed. Kritik der reinen Vemunft, 1787) Critique of Pure Reason, London: Penguin Classics.

Kant, I. (2007b) (or. ed. Kritik der Urtheilskraft, 1790) Critique of Judgement, Oxford: Oxford University Press.

Kant, I. (2012) (or. ed. Kritik der praktischen Vemunft, 1788) Critique of Practical Reason, New York: Dover Publications.

Origgi, G. (2015) 'La verità, nient'altro che la verità? Piccola storia filosofica della menzogna', MicroMega. Almanacco di filosofia, 2015/2: 83-97.

Rawls, J. (2005) Political Liberalism, New York: Columbia University Press.

Schopenhauer, A. (1995) (or. ed. Die Welt als Wille und Vorstellung, 1818/19 [I] - 1844 [II] 1859 [III]) The World as Will and Representation, E. F.J. Payne (ed.), New York: Dover Publications.

Sorrentino, V. (2013) 'Hannah Arendt. Verità, politica e mondo comune', in: A. Besussi (ed.), Verità e politica. Filosofie contemporanee, Roma: Carocci.

Sorrentino, V. (2017) 'La politica tra visibile e invisibile. Sul concetto di sfera pubblica in Hannah Arendt', Politica \& Società 2: 259-74.

Soubhik et al. (2020) Evaluating COVID-19 Public Health Messaging in Italy: Self-Reported Compliance and Growing Mental Heaith Concems, Working paper, 24 March 2020, https:// gking.harvard.edu/covid-italy (last consulted 1 April 2020).

Urbinati, N. (2019) Io, il popolo. Come il populismo trasforma la democrazia, Bologna: Il Mulino. Weber, M. (2004) (or. ed. Wissenschalft als Benuf, 1919) The Vocation Lectures, D. Owen, T.B. Strong (eds), Indianapolis - Cambridge: Hackett Publishing Company. 